\section{Vegetatively Propagated Geraniums Respond Similarly to Drench Applications of
Paclobutrazol or
Uniconazole}

\author{
Brian E. Whipker, ${ }^{1}$ \\ Shravan K. D asoju, ${ }^{2}$ and \\ M ichael R. Evans ${ }^{3}$
}

Additional index words. Pelargonium xhortorum, growth retardant

SUmmary. D rench applications of paclobutrazol or uniconazole were applied at doses of $0,0.0025,0.005$, $0.01,0.02$, or $0.04 \mathrm{mg}$ a.i./ pot $(28,350 \mathrm{mg}=1.0 \mathrm{oz})$ to vegetatively propagated 'Aurora', 'M edallion D ark Red', and 'Pink Satisfaction' geranium (Pelargonium xhortorum L.H . Bailey). Geranium total plant height, leaf canopy height, and plant diameter responded similarly to drench applications of either paclobutrazol or uniconazole. There was a significant quadratic relationship between plant growth regulator (PG R) dose and total plant height and leaf canopy height for 'Aurora' and 'Medallion D ark R ed', with total plant height and leaf canopy height being shorter as paclobutrazol

I owa Agriculture and $\mathrm{H}$ ome Economics Experiment Station journal paper J-18079, project 3345. Supported by $\mathrm{H}$ atch Act and State of I owa funds. This research was funded in part by the $\mathrm{N}$ orth $\mathrm{C}$ arolina Agricultural Research Service (N CARS), Raleigh. U se of trade names in this publication does not imply endorsement by the NCARS of products named nor criticism of similar ones not mentioned. Thanks to $O$ glevee L td., C onnellsville, $\mathrm{Pa}$., for supplying cuttings and to U niroyal Chemical $\mathrm{Co}$. and $\mathrm{V}$ alent $\mathrm{C}$ hemical $\mathrm{C}$. for grant support. The cost of publishing this paper was defrayed in part by the payment of page charges. U nder postal regulations, this paper therefore must be hereby marked adverti sement solely to indicate thisfact.

${ }^{1}$ Assistant professor, Dept. of $\mathrm{H}$ orticultural Science, Box 7609, N orth Carolina State U niv., Raleigh, NC 27695-7609.

${ }^{2}$ Former research associate, D epartment of $\mathrm{H}$ orticulture, I owa State U niv., Ames, I A 50011-1100.

${ }^{3}$ Assistant professor, D epartment of $\mathrm{H}$ orticulture, I owa State U niv., Ames, IA 50011-1100. or uniconazole doses increased up to $0.02 \mathrm{mg}$. H owever, doses of $\geq 0.02 \mathrm{mg}$ had little additional effect on total plant height and leaf canopy height. M ost of the total height control achieved by the use of PG Rs was primarily due to a reduction of leaf canopy height, rather than inflorescence height. D oses of 0.005 to 0.01 $\mathrm{mg}$ of either PG R produced marketable sized potted plants of 'M edallion D ark Red' and 'Pink Satisfaction'. 'Aurora', which was the most vigorous cultivar, required doses of 0.01 or $\mathbf{0 . 0 2}$ mg of either paclobutrazol or uniconazole to produce marketable sized potted plants.

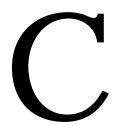

hemical plant growth regulators (PGRS) are applied to both seed and vegetatively propagated geraniumsto control plant height and improve overall appearance. Paclobutrazol ( (+)$\left(R^{*}, R^{*}\right)-\beta([4-c h l o r o p h e n y l]$ methyl)$\alpha$ - (1,1-dimethylethyl) - $1 \mathrm{H}-1,2,4$ triazole-1-ethanol) (Bonzi, U niroyal Chemical, Middlebury, Conn.) drenches of 0.01 to $0.5 \mathrm{mg}$ a.i./ pot suppressed plant height of seed propagated geraniums (Shanks, 1980). Cox and Keever (1988) conducted studies with paclobutrazol to control height of seed propagated geraniums and found root substrate drenches of 0.0075 or $0.015 \mathrm{mg}$ or a single foliar spray of 20 or $40 \mathrm{mg} \cdot \mathrm{L}^{-1}$ (ppm) were effective in controlling height and producing a marketable plant. Excessively short plants resulted when higher drench or foliar spray doses were used. N ørremark and Andersen (1990) also found paclobutrazol drench applications of $\geq 0.05 \mathrm{mg}$ resulted in seed geraniumswhich were excessively short and new growth continued to be retarded throughout the summer. U niconazole ((E)-1-(p-chlorphenyl)4,4-dimethyl-2-(1,2,4-triazol-1-yl-1penten-3-ol)) (Sumagic, V alent U SA, $M$ arysville, O hio) drenches of 0.025 to $0.1 \mathrm{mg}$ were applied to two cultivars of seed geraniums and doses of 0.025 were found to be effective for growth control, while higher doses were excessive (Starman et al., 1994).

Vegetatively propagated geraniums are typically more vigorous than seed propagated geraniums. A limited number of scientific studies have been conducted on the response of vegetatively propagated geraniums to paclobutrazol or uniconazolesubstrate drenches. Foliar applications of paclobutrazol at $15 \mathrm{mg} \cdot \mathrm{L}^{-1}$, applied twice, or uniconazole at $10 \mathrm{mg} \cdot \mathrm{L}^{-1}$, applied twice, resulted in effective height control and the production of marketable plants(T ayamaand C arver, 1990). The same doses of these PG R s applied as substrate drenches resulted in excessive suppression of growth (Tayama and C arver, 1990). A similar study indicated that uniconazole applied at 0.6 to $1.2 \mathrm{mg}$ as a substrate drench was excessive on vegetatively propagated geraniums, however this study did not include lower doses and a recommended commercial rate was not given (T ayama and C arver, 1992). While some studies have involved either paclobutrazol or uniconazole, none have directly compared similar doses of both chemicals over a wide range of concentrations on vegetatively propagated geraniums. This study was conducted to compare the effectiveness of paclobutrazol and uniconazole drenches at similar doses on plant growth of vegetatively propagated geraniums.

\section{Materials and methods}

Rooted vegetative cuttings of 'Aurora', 'M edallion D ark R ed', and 'Pink Satisfaction' geraniumswerepotted into 0.6-L (0.16-gal), 10-cm-diameter (4inch), squarepotson 18 Feb. 1996. The root substrate contained 2 soil : 5 sphagnum peat : 3 perlite (by volume) and was amended with ground dolomitic limestone to $\mathrm{pH}$ 5.1. Plants were fertilized at each watering $\left(\mathrm{mg} \cdot \mathrm{L}^{-1}\right)$ with 155 N , $21 \mathrm{P}$, and $127 \mathrm{~K}$. G reenhouse day/ night set points were $24 / 18{ }^{\circ} \mathrm{C}$ (75/ $\left.65^{\circ} \mathrm{F}\right)$, and the plants were grown under natural daylength with average light levels of $250 \mu \mathrm{mol} \cdot \mathrm{m}^{-2} \cdot \mathrm{s}^{-1}$ at $12: 00$ HR. Growth retardants were applied to the root substrates $21 \mathrm{~d}$ after planting. A volume of $89 \mathrm{~mL}(3 \mathrm{oz})$ of solution containing $0,0.0025,0.005$, $0.01,0.02$ or $0.04 \mathrm{mg}$ paclobutrazol or uniconazole was applied per container. The experiment was a completely randomized design with 10 single-plant replications of the 11 treatments. O n 8 M ay, leaf canopy height (measured from the pot rim to the top of thefoliage) , total plant height (measured from the pot rim to thetop of the inflorescence), and plant diameter (measured at the widest dimension, measured again after a turn of $90^{\circ}$, then averaged) were recorded for all plants. 
T able 1. Regression coefficients of models for total plant height and leaf canopy height of 'Aurora', 'M edallion Dark Red' and 'Pink Satisfaction' vegetatively propagated geraniums.'

\begin{tabular}{|c|c|c|c|c|}
\hline $\begin{array}{l}\text { Plant part } \\
\text { and cultivary }\end{array}$ & Regression equation & $\mathbf{r}^{2}$ & $\begin{array}{l}\text { Adjusted } \\
\mathbf{r}^{2}\end{array}$ & $\begin{array}{c}\text { R egression } \\
\text { F statistic }\end{array}$ \\
\hline \multicolumn{5}{|l|}{ Total plant height $(\mathrm{cm})$} \\
\hline Aurora & $y=28.1^{* * *}-480.46(\text { conc })^{* *}+6431.45\left(\text { conc }^{2}\right)^{* * *}$ & 0.714 & 0.709 & 146.2 \\
\hline M edallion D ark Red & $y=24.17^{* * *}-369.25(\text { conc })^{* * *}+4567.14\left(\text { conc }^{2}\right)^{* *}$ & 0.531 & 0.523 & 66.2 \\
\hline Pink Satisfaction & $y=23.48^{* * *}-170.98(\text { conc })^{* * *}$ & 0.552 & 0.548 & 145.4 \\
\hline \multicolumn{5}{|l|}{ Leaf canopy height $(\mathrm{cm})$} \\
\hline Aurora & $y=19.13^{* * *}-446.26(\text { conc })^{* * *}+6331.45\left(\text { conc }^{2}\right)^{* * *}$ & 0.641 & 0.635 & 104.6 \\
\hline M edallion D ark Red & $y=14.31^{* * *}-246.2(\text { conc })^{* * *}+3299.46\left(\text { conc }^{2}\right)^{* * *}$ & 0.523 & 0.515 & 64.1 \\
\hline Pink Satisfaction & $y=13.79^{* * *}-112.11$ (conc) $)^{* * *}$ & 0.477 & 0.473 & 107.8 \\
\hline
\end{tabular}

${ }^{2}$ Theplants were drenched with $0,0.0025,0.005,0.01,0.02$, or $0.04 \mathrm{mg}$ a.i./ pot of paclobutrazol or uniconazole. Total plant height and leaf canopy height werenot significantly influenced by plant growth regulator (PGR) type (paclobutrazol or uniconazole) and therefore the data were pooled across PGR type; $28,350 \mathrm{mg}=1.0 \mathrm{oz}$.

y $2.54 \mathrm{~cm}=1.0$ inch.

Significant at $\mathrm{P} \leq 0.01$ or 0.001 , respectively.

Data analysis. $D$ ata for the total plant height, leaf canopy height, and plant diameter were analyzed using analysis of variance by general linear model procedures(SASI nstitute, Cary, N.C.). M eans were separated by least significant differences (LSD) at $P \leq 0.05$.

Total plant height and leaf canopy height werenot significantlyinfluenced by PGR type (paclobutrazol or uniconazole) and therefore, data were pooled across PGR type. Total plant height and leaf canopy height values were regressed using the PROC REG procedure (SAS Institute, Cary, NC) to determine the best fit linear or quadratic model. Variables in the model were PGR concentration (conc) and indicator variables for cultivar (cult), with the full model being as follows: Concentration $_{1}=\beta_{0}+\beta_{1}$ Cult $_{2}+\beta_{2}$ Cult $_{3}$ $+\beta_{3}$ Conc $+\beta_{4}$ Conc $\times$ Cult $_{2}+$ $\beta_{5}$ Conc $\times$ Cult ${ }_{3}+\beta_{6}$ Conc $^{2}+\beta_{7}$ Conc $^{2} \times$ $\mathrm{Cult}_{2}+\beta_{8}$ Conc $^{2} \times \mathrm{Cult}_{3}$

where concentration $=P G R$ concentration $(0,0.0025,0.005,0.01,0.02$, or $0.04 \mathrm{mg}), \mathrm{i}=$ variable being regressed (total plant height or leaf canopy height); Cult $_{2}=1$ if cultivar $=$ 'M edallion Dark Red', 0 otherwise (for 'Aurora' or 'Pink Satiffaction'); Cult $_{3}=1$ if cultivar = 'Pink Satisfaction', 0 otherwise (for 'Aurora' or ' $M$ edallion $D$ ark Red') (when Cult $=$ 0 and Cult $_{3}=0$, then Cult ='Aurora'); $\beta_{k}=$ estimated coefficients ( $k=0$ to 8 ).

Terms of the model were judged to be significant or nonsignificant and included in the final model based on a comparison of $F$ values at $\alpha=0.05$.

Plant diameter was not significantly influenced by either PGR type or cultivar and the data was pooled. The concentration values were regressed using the PROC REG proce- dures outlined above to determine the best fit linear or quadratic model.

\section{Results and discussion}

There were significant cultivar $x$ dose interactions for total plant height and leaf canopy height $(P \leq 0.001)$. Therefore, the height data were analyzed by cultivar.

There was a significant quadratic relationship between the dose and total plant height for 'Aurora' and 'M edallion D ark Red', while 'Pink Satisfaction' responded linearly (Table 1 ).
Total plant height of 'Aurora' was reduced as paclobutrazol or uniconazole dose increased up to 0.02 mg. H owever, additional increases in dose had little effect on total plant height. 'Aurora' plants treated with $0.01 \mathrm{mg}$ of paclobutrazol or uniconazole were $15 \%$ shorter than the untreated plants. U ntreated control plants of 'Aurora' were $27.8 \mathrm{~cm}$ (10.8 inches), while ' $M$ edallion $D$ ark Red' and 'Pink Satisfaction' were shorter $[23.9 \mathrm{~cm}$ ( 9.3 inches) and 23.3 cm (9.1 inches), respectively]. 'M edal-

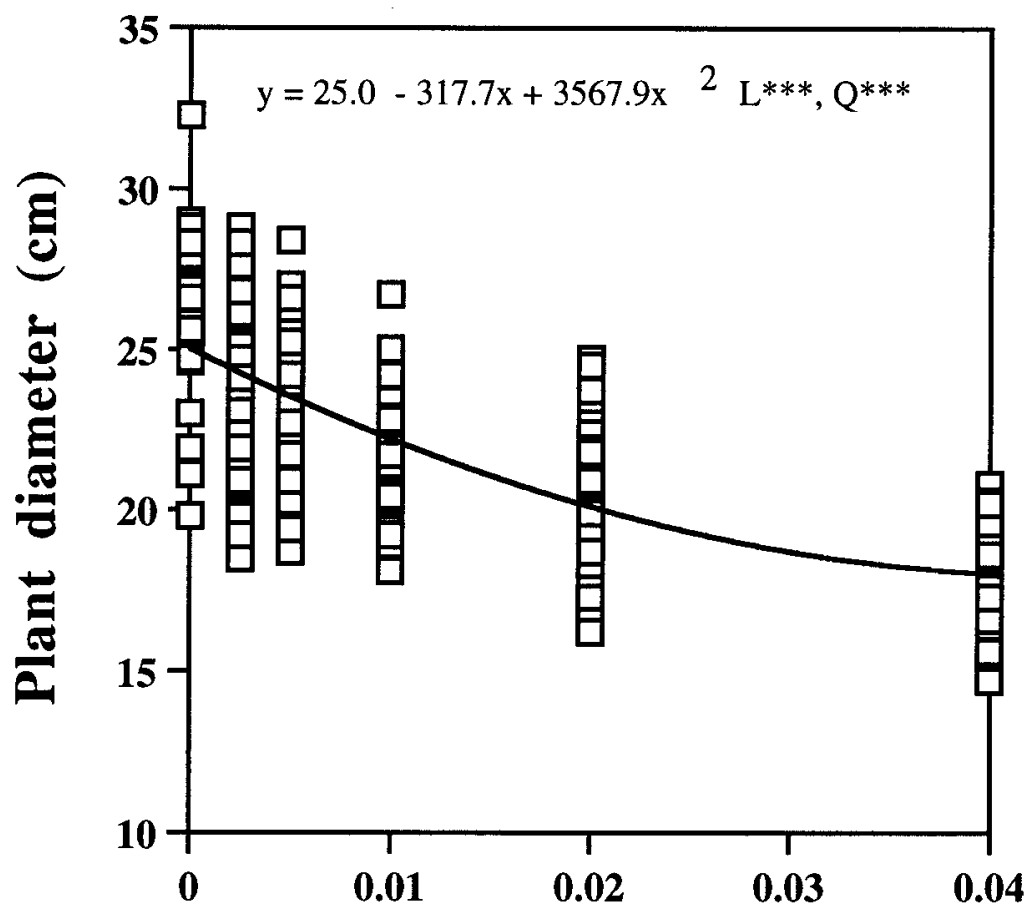

Fig. 1. Effect of paclobutrazol or uniconazole ( $\mathrm{mg}$ a.i./pot) on plant diameter of vegetatively propagated geraniums. Data pooled across plant growth regulator (PG R ) type and cultivar. Plant diameter significant at $\mathbf{P} \leq \mathbf{0 . 0 0 1}$ for the PG R dose and LSD $(\alpha \leq 0.05)$ is $1.0 \mathrm{~cm}\left(0.39\right.$ inch). The adjusted $r^{2}$ for plant diameter was 0.59 . ${ }^{* *}$ Significant at $\mathbf{P} \leq 0.001$. $\mathbf{L}=$ linear and $\mathrm{Q}=$ quadratic; $28,350 \mathrm{mg}=1.0 \mathrm{oz}$. 
lion D ark Red' and 'Pink Satiffaction' were shorter cultivars, however they had a response similar to 'Aurora' for total plant height as the PGR dose increased. Excessive height retardation of all three cultivars was evident at doses of $0.04 \mathrm{mg}$, with plants being $31 \%, 30 \%$ and $28 \%$ shorter than the untreated control, respectively, for 'Aurora', 'M edallion Dark Red', and 'Pink Satisfaction'. These results were similar to other experiments which indicated excessively short plants of seed or vegetatively propagated geraniums resulted from drench applications of either paclobutrazol (Nørremark and Anderson, 1990; Tayama and Carver, 1990) or uniconazole (Starman et al., 1994; Tayama and ( arver, 1990; 1992) at doses of $\geq 0.05 \mathrm{mg}$.

At $19.5 \mathrm{~cm}$ (7.6 inches), the leaf canopy height of untreated control plants of 'Aurora' were taller than either ' $M$ edallion Dark Red' or 'Pink Satisfaction', which were $14.8 \mathrm{~cm}(5.8$ inches) and $13.9 \mathrm{~cm}$ (5.4 inches), respectively ( $T$ able 1). L eaf canopy height of 'Aurora' and 'M edallion D ark R ed' were $32 \%$ and $26 \%$ shorter than the untreated control, respectively, as paclobutrazol or uniconazole doses increased up to $0.02 \mathrm{mg}$. H owever, additional increases in dose had little effect on leaf canopy height of 'Aurora' and 'M edallion D ark Red'. M ost of the height control achieved by the use of PGRs was primarily due to a reduction of leaf canopy height, rather than inflorescence height and similar resultswerereported with uniconazole drenches on seed propagated geraniums (Starman et al., 1994).

Plant diameter of vegetatively propagated geraniums was significantly different $(P \leq 0.001)$ only for $P G R$ dose, therefore the data was pooled across cultivars and PGR type. There was a significant quadratic relationship for plant diameter as the PGR dose increased (Fig. 1). Plant diameter was smaller as the PGR dose increased, with plants treated with $0.02 \mathrm{mg}$ were $22 \%$ smaller than the untreated control, and those treated with $0.04 \mathrm{mg}$ were $31 \%$ smaller than theuntreated control. Plants treated with $0.04 \mathrm{mg}$ of paclobutrazol or uniconazolehad smaller, darker green leaves and stunted growth.

\section{Conclusions}

The vigor and responsiveness of vegetatively propagated geranium cultivars should be considered when determining the optimal drench dose of a PGR. 'Aurora' was the most vigorous cultivar, with a total plant height of $27.8 \mathrm{~cm}$ (10.8 inches) for the untreated control. D rench doses of paclobutrazol or uniconazole of 0.01 to $0.02 \mathrm{mg}$ per container produced marketable sized potted plants. Both 'M edallion D ark Red' and 'Pink Satisfaction' were less vigorous, and lower paclobutrazol or uniconazole drench rates of 0.005 to $0.01 \mathrm{mg} /$ container produced marketable plants. 0 ur recommendation of 0.01 to $0.02 \mathrm{mg}$ of paclobutrazol or uniconazole per container on vegetatively propagated 'Aurora' geraniums is similar to those for seed propagated geraniums of 0.025 $\mathrm{mg}$ of uniconazole recommended by Starman et al. (1994) and the range of 0.0075 or $0.015 \mathrm{mg}$ of paclobutrazol by Cox and Keever (1988). Based upon our results and those of $C$ ox and Keever (1988), and Starman et al. (1994), we have concluded that vegetative and seed propagated geraniumsrespond similarly to paclobutrazol or uniconazole drenches. Thisconclusion is in contrast to the responses of many ornamental species in which an equivalent dose of unico nazole resulted in greater height reduction compared to paclobutrazol (Barrett et al., 1986; Wilfret, 1990).

G rowers have a number of PGRs available for controlling plant growth. Thetype of PGR used to control growth of vegetatively propagated geraniums should be based on the response of the plant and the cost of the PGR. In foliar PGR experiments, Whipker etal. (1997) recommended paclobutrazol foliar sprays between 5 and $15 \mathrm{mg} \cdot \mathrm{L}^{-1}$ at a PGR cost of less than $\$ 0.001$ per $0.6-L$ (0.16-gal) pot. Based on the cost of $\$ 97 / \mathrm{L}(\$ 102 / \mathrm{qt})$ for paclobutrazol or
$\$ 74 / \mathrm{L}$ (\$78/ qt) for uniconazole, the 0.02-mg drench would also cost less than $\$ 0.001$ per $0.6-\mathrm{L}$ (0.16-gal) pot. With a similar degree of growth control and similar costs per pot available with either paclobutrazol or uniconazole drench doses of 0.005 to $0.02 \mathrm{mg}$ or paclobutrazol foliar sprays between 5 and $15 \mathrm{mg} \cdot \mathrm{L}^{-1}$, growers would find the chemical cost of any of these PG R application methods to be economical.

\section{Literature cited}

Barrett, J.E., M .E. Peacock, and T .A. N ell. 1986. H eight control of exacum and chrysanthemum with paclobutrazol, XE-1019, flurprimidol and RSW-0411. Proc. Fla. State H ort. Soc. 99:254-255.

Cox, D.A. and G.J. Keever. 1988. Paclobutrazol inhibits growth of zinnia and geraniums. HortScience 23:10291030.

Nørremark, I. and A. Andersen. 1990. Effect of paclobutrazol on seed propagated Pelargonium xhortorum L.H . Bailey. Gartenbauwissenschaft 55:1-8.

Shanks, J.B. 1980. Chemical dwarfing of several ornamental greenhouse crops with PP333, p. 46-51. Proc. VII Annu. M eeting of the Plant G rowth Regulat. Working Group. Great Western Sugar Co., Longmont, Colo.

Starman, T.W., T.A. Cerny, and T.L. Grindstaff. 1994. Seed geranium growth and flowering responses to uniconazole. H ortScience 29:865-867.

Tayama, H .K. and S.A.C arver. 1990. Zonal geranium growth and flowering responses to six growth regulators. $\mathrm{H}$ ortScience 25:82-83.

Tayama, H.K. and S.A. Carver. 1992. Concentration response of zonal geranium and potted chrysanthemum to uniconazole. H ortScience 27:126-128.

Whipker, B.E., P.A. H ammer, and J. Connell. 1997. Vegetatively propagated geranium response to single and multiple applications of chemical growth retardants. Plant Growth Regulat. Soc. Amer. Q uart. 25(3):131-133.

Wilfret, G.J. 1990. H eight control of potted E aster liliesin F lorida. Fla. O rnamental Growers Assn. N wsl. 13(1):1-3. 